\title{
Long-term adaptation of Daphnia to toxic environment in Lake Orta: the effects of short-term exposure to copper and acidification
}

\author{
Benedetta PONTI, Roberta PISCIA, Roberta BETTINETTI ${ }^{1)}$ and Marina MANCA* \\ CNR Institute of Ecosystem Study, Largo V. Tonolli 50, 28922 Verbania Pallanza, Italy \\ ${ }^{1)}$ Department of Chemical and Environmental Sciences, University of Insubria, Via Valleggio 11, 22100 Como, Italy \\ *e-mail corresponding author:m.manca@ise.cnr.it
}

\begin{abstract}
Because of its 80-year history of heavy pollution and re-colonization, Lake Orta provides a good opportunity for investigating the response of zooplankton organisms to heavy metals and acidification as well as the mechanisms involved. After the recent establishment of Daphnia galeata Sars, and the detection of an extremely low clonal diversity of Lake Orta population, we carried out a study to investigate the lethal tolerance to ionic copper, as well as to acidity, and the impact of newborn Daphnia exposure to sublethal concentrations of copper for their later development and reproduction. We conducted acute toxicity tests to estimate the EC50 for ionic copper and tolerance to low $\mathrm{pH}$, as well as life table experiments. Tolerance to ionic copper was high, three times that reported in literature. An increased mortality soon after exposure to low pH confirmed a high sensitivity to acidity and explained the success of the species in Lake Orta only after pH recovery. An analysis of reproductive and demographic parameters revealed that D. galeata Sars was stressed at concentrations of ionic copper only twice higher than those presently recorded in the lake (i.e., ca 3 $\left.\mu g L^{-1}\right)$. An increased cumulative number of eggs produced by each female were in fact counterbalanced by an increasing abortion rate, which resulted in an unaltered or lower intrinsic rate of population increase. Our results are likely due to the strong selective pressure, more than physiological processes (acclimation), in a polluted area in which only specific adapted clones are able to grow, confirming the results previously obtained on Lake Orta's D. obtusa Kurz population. The reproductive response and the relatively low within treatment variability suggest that clone specificity, rather than physiological acclimation, was the driving force. The low variability confirmed results previously obtained from life tables experiments on Lake Orta's D. obtusa clone. Overall, our results suggest that, despite the chemical recovery, Lake Orta may be regarded as highly vulnerable to biodiversity loss.
\end{abstract}

Key words: ecotoxicology, reproduction, growth, fertility, cladocerans

\section{INTRODUCTION}

Although copper is an essential micronutrient needed for normal plant and animal growth and development, it can be an important toxic contaminant in aquatic systems because of a high sensitivity of organisms to certain ionic forms and the tendency of copper to bioaccumulate (Long et al. 2004). Contamination of aquatic systems by metals may cause adverse effects on ecological balance and species diversity; aquatic animals, however, have the capacity to increase tolerance to metal toxicity.

Such tolerance may be the result of physiological processes (acclimation) or have a genetic basis (adaptation) (Barata et al. 1998; Muyssen et al. 2002; Bossuyt \& Janssen 2003). The two different response strategies have important consequences: while in the case of acclimation, rapid environmental changes may be buffered through physiological plasticity, this may not be the case under strong genetic selection leading to low clone diversity.

Evidence for the development of a resistance through acclimation was provided by Muyssen et al. (2002). These Authors found that Daphnia magna clones from ponds that were polluted by zinc, were able to tolerate higher concentrations of ionic zinc when cultured in their ambient water. Such tolerance however, decreased or disappeared when the same clone was again exposed to the toxicant, after being maintained in unpolluted water. Similarly, LeBlanc (1982) found that exposure of daphnids to ionic copper for a number of generations allowed for the development of a high level of tolerance. An extraordinary and constant monomorphism on the level of allozymes in a natural population of Daphnia pulex Leydig from a small lake in Germany was interpreted as a result of a combination of a founder effect and a strong selection pression consequent to a 15-year biomanipulation (Matthes 2004).

Lake Orta is an interesting ecosystem because of its history of pollution, recovery and re-colonization. Zooplankton, particularly Daphnia, has been the object of long-term investigations; this allowed for tracing the appearance, success and decline of different species along with the recovery. The re-colonization of the lake by D. obtusa Kurz was ascribed to the establishment of a single clone, which was able to better grow and reproduce under polluted conditions in Lake Orta, than in nearby unpolluted Lake Maggiore (Bachiorri et al. 1991a). Net reproduction was higher, and variability lower, when specimens were cultured in Lake Orta water than in unpolluted water (Bachiorri et al. 1991b). The low clonal diversity and poor ability to adapt to 


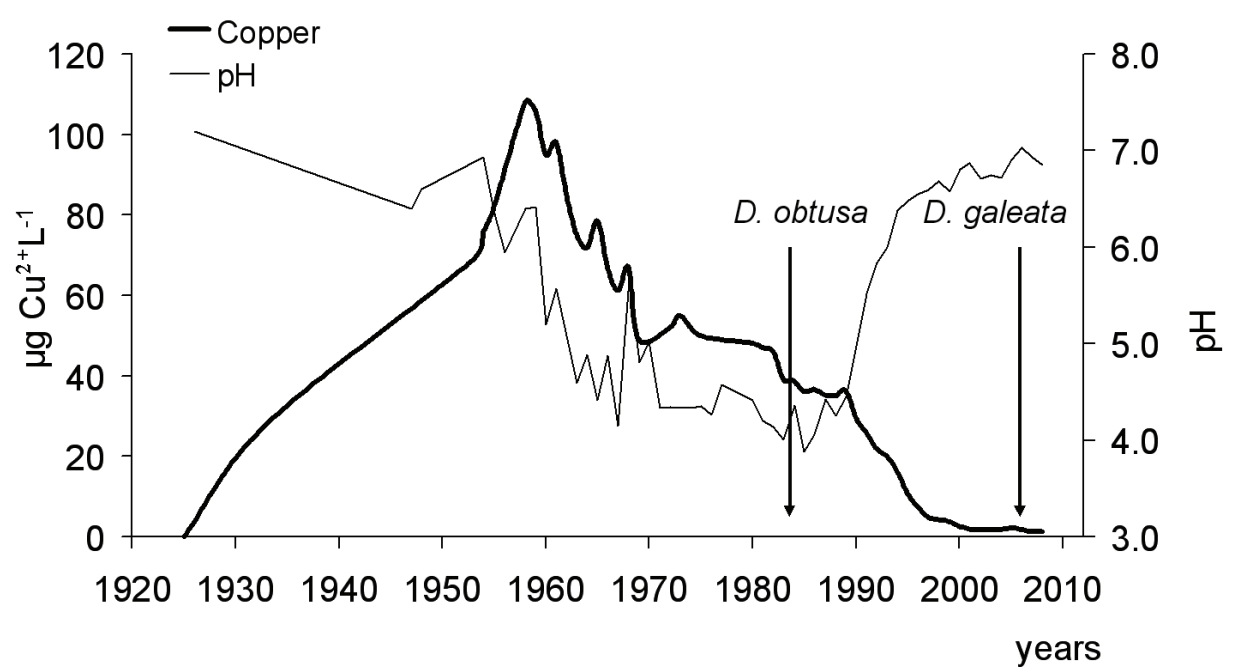

Fig. 1. Changes in $\mathrm{pH}$ and ionic copper concentration in Lake Orta before, during, and after the pollution.

increasing $\mathrm{pH}$ (from 5 to 7 ) also provided an explanation for the disappearance of D. obtusa when $\mathrm{pH}$ was restored and zooplanktivorous fish were again detected in the lake (Hamza et al. 1998; Bonacina \& Pasteris 2001).

The more recent success in Lake Orta of $D$. galeata Sars, a second daphnid which colonized the lake during its recovery, offered an opportunity for testing the response of the species to ionic copper and low $\mathrm{pH}$. Given the peculiarity of the environment and the monoclonal nature of the D. galeata population (Piscia et al. 2006), we hypothesized that Lake Orta $D$. galeata would be able to tolerate ionic copper concentrations higher than those reported in literature. We also aimed to investigate if the life history traits of $D$. galeata were altered after pre-exposing newborn to sub-lethal concentrations of ionic copper. In addition, the lethal effect of $\mathrm{pH}$ was also tested to determine if the colonization of Lake Orta by this species was influenced by the recovery from acidification.

\section{THE STUDY SITE}

Located in Northern Italy, Lake Orta is the seventh largest Italian lake by volume. The lake became notorious for its chronic pollution, caused by the discharge of huge amounts of copper and ammonium sulphate from a rayon factory, established at the southern end of the lake in 1926 (Fig. 1) (Calderoni et al. 1990). The discharge of ammonium sulphate did not initially result in an increase of in-lake ammonium concentrations. Instead, biochemical oxidation of $\mathrm{N}-\mathrm{NH}_{4}$ caused nitrate $\left(\mathrm{N}-\mathrm{NO}_{3}\right)$ to accumulate in the lake in the 1950 's. Already poorly buffered (total alkalinity ranging between 0.3-0.4 meq $\mathrm{L}^{-1}$ ) because of the geology of the catchment basin, the lake underwent progressive acidification (to $\mathrm{pH} 4.0$ ) along with increasing ionic copper concentration (to a maximum of $85 \mu \mathrm{g} \mathrm{L}^{-1}$ during winter mixing). The discharge of these pollutants stopped in 1980, four years after the approval by the Italian Parliament of a law on the regulation of the discharge of industrial wastes into freshwater environments. The lake recovery was rapid, further accelerated after a liming intervention in 19891990.

Before industrial pollution, the zooplankton was composed by seven species of cladocerans (four of which belonging to the genus Daphnia) (Pavesi 1879), five species of copepods and several rotifers (Monti 1930). The response of the biota to pollution was monitored from the early phases through the progressive depletion of nearly all life forms from the lake (Bonacina 2001).

Zooplankton reacted to the chemical recovery: following the re-colonization by rotifers, the allochthonous D. obtusa, a tolerant species of stressed environments (Fryer 1985), was recorded in the lake for the first time. The gradual re-colonization was accompanied by remarkable changes in community structure and size (Manca \& Comoli 1995; Cattaneo et al. 1998) and by specific traits related to the specific environmental conditions (Ruggiu et al. 1998), which imposed strong selection (Bachiorri et al. 1991a; Bonacina et al. 1994).

Large interannual and seasonal variations in $D$. obtusa population density were recorded between its colonization and 1996, when the species was replaced by a $D$. longispina, of the same morphotype as that found before the lake pollution (Bonacina 2001). D. longispina was recorded until 2001. At that time, a regular monitoring of the lake zooplankton detected an increasing complexity of the plankton community.

In 2004, during a survey of Italian subalpine lakes for a study on distribution of Daphnia parasites in hybrids and parental species of the D. hyalina-galeata complex (Wolinska et al. 2007), D. galeata Sars was detected in the lake; its population was almost exclusively composed by a single clone (July 2006; Piscia et al. 2006). 


\section{MATERIALS AND METHODS}

A laboratory clone of D. galeata was established from Lake Orta population in May 2008. A live sample was collected using a plankton net $(126 \mu \mathrm{m}$ nylon mesh size), from 0 to $50 \mathrm{~m}$ depth, at the regular monitoring station (Pettenasco, $183 \mathrm{~m}$ ). The clone was reared in the laboratory in aerated Lake Orta surface water filtered on $0.2 \mu \mathrm{m}$ pore size polycarbonate Nucleopore filters $(\mathrm{pH}$ $=7.4 ; \mathrm{Cu}^{2+}=3.2 \mu \mathrm{g} \mathrm{L}^{-1}$ ), enriched with a suspension of Kirchneriella subcapitata (Korshikov) to reach $80 \times 10^{3}$ cell $\mathrm{mL}^{-1}$. Temperature and duration of the photoperiod were kept constant at $20 \pm 1{ }^{\circ} \mathrm{C}$, and 12 Light: 8 Dark hrs. To avoid maternal effects (de Bernardi \& Manca 1981; Lampert 2000) neonates from the third generation were used for the experiments.

\subsection{Acute toxicity tests}

Acute toxicity assays were performed following OECD Protocol 202 (OECD 1996). Three replicates of ten newborn each $(<24 \mathrm{~h}$ age, each in $100 \mathrm{~mL}$ of test medium) were exposed to five treatments with ionic copper concentrations that ranged between 39-87 $\mu \mathrm{g}$

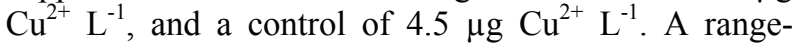
finding test was used to select the exposure concentrations. Treatment concentrations are reported as the average value of the measured concentrations (via ICP-OES inductive coupled plasma optical emission spectrometry) at time 0 and at time $48 \mathrm{hrs}$.

After 48 hrs, the number of immobilized organisms in each vessel was counted and ecotoxicity data were reported as EC50 with the 95\% confidence interval.

Tolerance of Lake Orta D. galeata to low $\mathrm{pH}$ was tested in a range between 4.5 and 5.5, which is representative of lake conditions just before and during the establishment of $D$. galeata. A transition from simple to complex zooplankton communities typically occurs between pH 5.0 and pH 5.5 (Keller et al. 1990; Locke 1991), as it was also reported during the recovery of Lake Orta (Hamza et al. 1998). Three replicates of ten newborn $(<24 \mathrm{~h}$ age $)$ each were reared individually in $100 \mathrm{~mL}$ Lake Orta $0.2 \mu \mathrm{m}$ filtered water $(\mathrm{pH}=7.0$, used as a control), acidified to 5.5 and to 4.5 by adding $\mathrm{HNO}_{3}$. After $48 \mathrm{hrs}$ the number of immobilized organisms in each vessel was counted.

\subsection{Life-tables experiments}

To assess the consequences of exposure of newborn D. galeata to sub-lethal concentrations of ionic copper, life tables experiments were run on organisms which survived $48 \mathrm{hrs}$ exposure to $\mathrm{Cu}^{2+}$ concentrations between 3.2 and $6.9 \mu \mathrm{g} \mathrm{L}^{-1}$. The former was chosen as a control, as it corresponds to present-day $\mathrm{Cu}^{2+}$ concentration in Lake Orta, while the latter is representative of lake conditions near the time when D. galeata established in the lake.
Test organisms were kept in the laboratory (one Daphnia/beaker; 45 individuals in total) under the same conditions as previously described. The culture medium was refreshed every other day, when body length was measured and the number of eggs and neonates produced by each female was counted. The experiments lasted 45 days, which is the mean life expectancy of $D$. galeata under non-limiting food conditions (de Bernardi \& Manca 1982).

From the data obtained, we estimated: the number of survivors in each age class $\left(l_{x}\right)$, the age-specific fecundity $\left(m_{\text {xeggs }}\right)$ and fertility $\left(m_{\text {xnewborn }}\right)$, the survivorshipweighted fecundity $\left(l_{x} m_{\text {xeggs }}\right)$ and fertility $\left(l_{x} m_{\text {xnewborn }}\right)$, the net fecundity $\left(R_{\text {oeggs }}=\Sigma l_{x} m_{\text {xeggs }}\right)$ and fertility $\left(\mathrm{R}_{\text {nnewborn }}=\Sigma l_{x} m_{\text {xnewborn }}\right)$, as well as the mean generation time $\left(\mathrm{T}=\Sigma x \times l_{x} m_{x} / \Sigma l_{x} m_{x}\right)$ (Seber 1973). The intrinsic rate of natural increase was calculated as $\left(r=\mathrm{Ln} R_{0} / T\right)$. Age and size at first reproduction and at the release of newborn were also recorded. We also measured the $1^{\text {st }}$ offspring biomass ( $\mu \mathrm{g}$ d.w., from length/weight regression equation; Manca \& Comoli 2000), which is often used as a measure for fitness. Somatic growth over the whole period of the experiment was also estimated. The total number of clutches and of offspring releases/female were also recorded over 45 days of experiment.

\subsection{Statistical analysis}

The Effect Concentration at 48 hours (48 h EC50) was estimated by the probit analysis using the EPA Probit analysis programme.

A jackknife resampling method was used to estimate the variability and standard error in demographic parameters obtained from life table experiments and compare them among the 4 treatments (Meyer et al. 1986).

The effect of copper pre-exposure on the daphnids' demographic and reproductive parameters was tested using one-way analysis of variance (ANOVA), and the statistical significance of between-treatment differences assessed through Scheffè's multiple-range test. When normality conditions were not verified (by Levene test), Kruskal-Wallis ANOVA and median test were used (STATISTICA version 6).

\section{RESULTS}

\subsection{8-hour acute toxicity tests for ionic copper and low $\mathrm{pH}$}

The calculated copper EC50 value (Tab. 1) was about 3 times higher (confidence intervals included) than that reported by Bossuyt \& Janssen (2005) for $D$. galeata clones obtained from a field population in Lake Leuven.

Mortality under acidic conditions $(\mathrm{pH}=5.5)$ was detected after $24 \mathrm{hrs}$ and at the end of the exposure reached $73 \%$ (Tab. 2). At $\mathrm{pH}=4.5$ immobilization 
Tab. 1. EC50 values (95\% Confidence Intervals) estimated for D. galeata after chronic (48 hrs) exposure to ionic copper (this study; $\mathrm{N}=180$ ). Values are compared with those reported in literature.

\begin{tabular}{|c|c|c|c|c|}
\hline Species & $\mathrm{Cu}^{++}\left(\mu \mathrm{g} \mathrm{L}^{-1}\right)$ & $\mathrm{pH}$ & Method & Reference \\
\hline $\begin{array}{l}\text { D. galeata } \\
\text { (Lake Orta) }\end{array}$ & $\begin{array}{c}67.2 \\
(64.7-69.6)\end{array}$ & $\begin{array}{c}5.4 \\
(4.9-5.6)\end{array}$ & EPA Probit Analysis & Present experiment \\
\hline $\begin{array}{c}\text { D. galeata } \\
\text { (Lake Leuven) }\end{array}$ & $\begin{array}{c}22.6 \\
(19.6-25.6)\end{array}$ & & Trimmed Sperman-Karber & Bossuyt \& Janssen, 2005 \\
\hline $\begin{array}{l}\text { D. galeata mendotae } \\
\text { (Lake Ontario) }\end{array}$ & & $\begin{array}{c}5.7 \\
(5.6-5.8)\end{array}$ & EPA Probit Analysis & Havens et al. 1993 \\
\hline
\end{tabular}

Tab. 2. Number of survivors of D. galeata of the acute toxicity test to $\mathrm{pH}$ (mean \pm 1.96 Standard Error).

\begin{tabular}{cccccc}
\hline $\mathrm{pH}$ & $0(\mathrm{hrs})$ & $12(\mathrm{hrs})$ & $24(\mathrm{hrs})$ & $36(\mathrm{hrs})$ & $48(\mathrm{hrs})$ \\
\hline 7.4 & 10 & 10 & 10 & 10 & 10 \\
& $(0)$ & $(0)$ & $(0)$ & $(0)$ & $(0)$ \\
5.5 & 10 & 10 & 9 & 8.3 & 7.3 \\
& $(0)$ & $(0)$ & $(1.13)$ & $(0.65)$ & $(0.65)$ \\
4.5 & 10 & 4.3 & 2 & 0.7 & 0 \\
& $(0)$ & $(0.65)$ & $(1.13)$ & $(0.65)$ & $(0)$ \\
\hline
\end{tabular}

Tab. 3. Main demographic and reproductive parameters (mean \pm 1.96 Standard Error) estimated from life table experiments on D. galeata after exposure (48 hrs) of newborn to ionic copper.

\begin{tabular}{|c|c|c|c|c|c|}
\hline $\mathrm{Cu}^{++}\left(\mu \mathrm{g} \mathrm{L}^{-1}\right)$ & 3.2 (control) & 3.9 & 4.9 & 5.1 & 6.9 \\
\hline $\begin{array}{l}\text { Age at first egg production } \\
\text { (AFEP, days) }\end{array}$ & $\begin{array}{c}8 \\
(0)\end{array}$ & $\begin{array}{c}6.5 \\
(0.08)\end{array}$ & $\begin{array}{c}6.8 \\
(0.05)\end{array}$ & $\begin{array}{c}6.6 \\
(0.07)\end{array}$ & $\begin{array}{c}8.8 \\
(0.05)\end{array}$ \\
\hline $\begin{array}{l}\text { Age at first newborn release } \\
\text { (AFNR, days) }\end{array}$ & $\begin{array}{l}11.3 \\
(0.07)\end{array}$ & $\begin{array}{c}9.8 \\
(0.10)\end{array}$ & $\begin{array}{c}9.1 \\
(0.48)\end{array}$ & $\begin{array}{c}9.5 \\
(0.16)\end{array}$ & $\begin{array}{c}11.3 \\
(0.07)\end{array}$ \\
\hline $\begin{array}{l}\text { Net fecundity } \\
\left(R_{0 \text { eggs }}\right)\end{array}$ & $\begin{array}{c}70 \\
(0.7)\end{array}$ & $\begin{array}{c}92 \\
(0.5)\end{array}$ & $\begin{array}{c}94 \\
(1.3)\end{array}$ & $\begin{array}{c}96 \\
(1.1)\end{array}$ & $\begin{array}{c}79 \\
(1.0)\end{array}$ \\
\hline $\begin{array}{l}\text { Net fertility } \\
\left(R_{0 \text { newborn }}\right)\end{array}$ & $\begin{array}{c}61 \\
(0.8)\end{array}$ & $\begin{array}{c}74 \\
(1.2)\end{array}$ & $\begin{array}{c}72 \\
(1.4)\end{array}$ & $\begin{array}{c}71 \\
(1.0)\end{array}$ & $\begin{array}{c}55 \\
(1.2)\end{array}$ \\
\hline $\begin{array}{l}\text { Mean generation time } \\
(\mathrm{T}, \text { days) }\end{array}$ & $\begin{array}{c}28 \\
(0.1)\end{array}$ & $\begin{array}{l}30 \\
(0.1)\end{array}$ & $\begin{array}{c}30 \\
(0.2)\end{array}$ & $\begin{array}{c}30 \\
(0.1)\end{array}$ & $\begin{array}{c}29 \\
(0.1)\end{array}$ \\
\hline $\begin{array}{l}\text { Intrinsic rate of increase } \\
\left(r, \text { day }^{-1}\right)\end{array}$ & $\begin{array}{c}0.146 \\
(0.001)\end{array}$ & $\begin{array}{c}0.145 \\
(0.001)\end{array}$ & $\begin{array}{c}0.144 \\
(0.001)\end{array}$ & $\begin{array}{c}0.142 \\
(0.001)\end{array}$ & $\begin{array}{c}0.138 \\
(0.001)\end{array}$ \\
\hline $\begin{array}{l}1^{\text {st }} \text { offspring production } \\
\text { (newborn total body mass, } \mu \mathrm{g} \text { d.w.) }\end{array}$ & $\begin{array}{c}28 \\
(1.2)\end{array}$ & $\begin{array}{c}8 \\
(1.0)\end{array}$ & $\begin{array}{c}9 \\
(0.9)\end{array}$ & $\begin{array}{c}7 \\
(0.9)\end{array}$ & $\begin{array}{c}5 \\
(1.7)\end{array}$ \\
\hline $\begin{array}{l}\text { Total number of egg } \\
\text { clutches/female }\end{array}$ & $\begin{array}{c}13 \\
(0.29)\end{array}$ & $\begin{array}{c}15 \\
(0.08)\end{array}$ & $\begin{array}{c}15 \\
(0.07)\end{array}$ & $\begin{array}{c}15 \\
(0.06)\end{array}$ & $\begin{array}{c}13 \\
(0.08)\end{array}$ \\
\hline $\begin{array}{l}\text { Total number of } \\
\text { newborn clutches/female }\end{array}$ & $\begin{array}{c}12 \\
(0.33)\end{array}$ & $\begin{array}{c}13 \\
(0.08)\end{array}$ & $\begin{array}{c}13 \\
(0.19)\end{array}$ & $\begin{array}{c}13 \\
(0.09)\end{array}$ & $\begin{array}{c}10 \\
(0.20)\end{array}$ \\
\hline $\begin{array}{l}\text { Somatic growth } \\
\text { (body mass, } \mu \text { g d.w.) }\end{array}$ & $\begin{array}{c}16 \\
(0.6)\end{array}$ & $\begin{array}{c}17 \\
(0.3)\end{array}$ & $\begin{array}{c}17 \\
(1.5)\end{array}$ & $\begin{array}{c}14 \\
(1.2)\end{array}$ & $\begin{array}{c}15 \\
(0.5)\end{array}$ \\
\hline
\end{tabular}

sharply increased immediately after the exposure, and reached values of $\mathrm{ca} 60 \%$ after $12 \mathrm{hrs}$. After $36 \mathrm{hrs}, 98 \%$ of individuals were dead, and at the end of the experiment $100 \%$ of individuals were immobilized and dead.

\subsection{Life table experiments}

The pre-exposure of newborn to different concentrations of ionic copper influenced reproductive and demographic parameters measured during a life table experiment carried out in the culture medium (Tab. 3).

Age at first reproduction (i.e. at first egg production, AFEP, in days) was shortened by 1-2 days after expo- sure of newborn to intermediate concentrations of ionic copper (between 6.5 and 6.8 days on average, compared to 8 days recorded in the control; Tab. 3). At $6.9 \mu \mathrm{g}$ $\mathrm{Cu}^{2+} \mathrm{L}^{-1}$, however, the age was very close to that recorded in the control. Overall, the number of egg clutches produced by each female over the entire experimental period was negatively correlated with the age at first egg production $(r=-0.75 ; p<0.001 ; \mathrm{N}=29)$.

Age at first release of newborn (AFNR, days) was similar between the control and the highest $\mathrm{Cu}^{2+}$ concentration, while it appeared shortened at concentrations between 3.9 and $5.1 \mu \mathrm{g} \mathrm{Cu}^{2+} \mathrm{L}^{-1}$. The earlier release of newborn was associated with an increased number of 


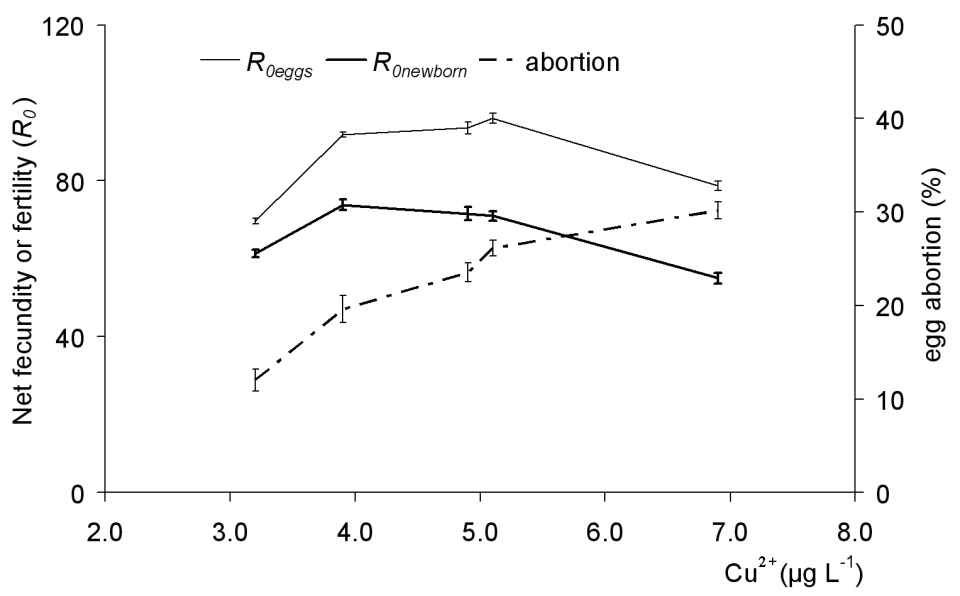

Fig. 2. Net fecundity $\left(R_{\text {leggs }}\right)$, fertility $\left(R_{\text {Onewborn }}\right)$ and percent of abortion of Lake Orta's $D$. galeata clone measured during 45 days experiments. Vertical bars show \pm 1.96 Standard Error.

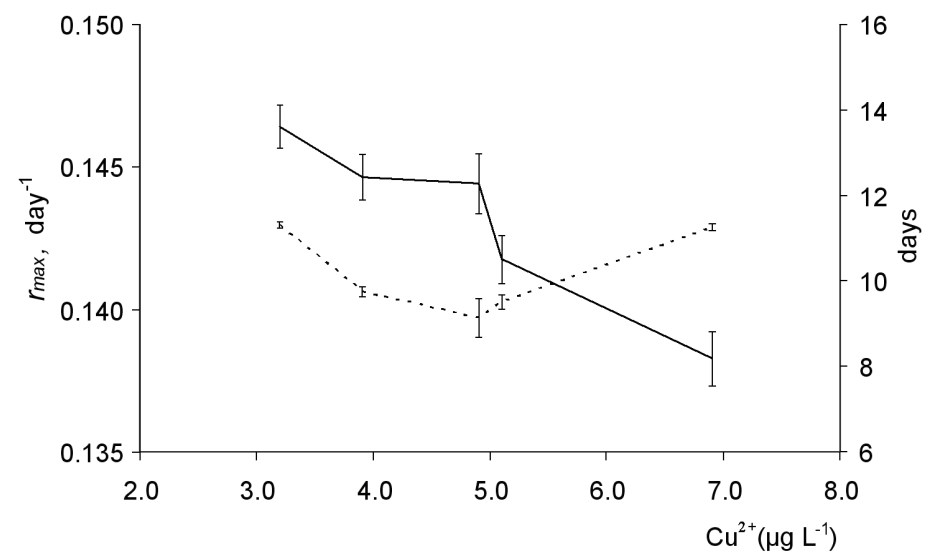

Fig. 3. Changes in the intrinsic rate of increase $\left(r_{\max }\right.$ day $\left.^{-1}\right)$ and in age at first reproduction (days, dotted line) (mean $\pm 1.96 \mathrm{Standard}$ Error) of Lake Orta's D. galeata clone after exposure to sub-lethal concentrations of ionic copper. For further explanation see text.

newborn clutches, while at $6.9 \mu \mathrm{g} \mathrm{Cu}^{2+} \mathrm{L}^{-1}$ significantly fewer clutches were produced despite a similar maternal age between the treatment and the control.

Net fecundity $\left(R_{\text {leggs }}\right)$ was enhanced in all treatments, and particularly at $5.1 \mu \mathrm{g} \mathrm{L}^{-1}$, compared to the control. The production of newborn $\left(R_{\text {onewborn }}\right)$ was also generally higher than in the control: only at the highest concentration $\left(6.9 \mu \mathrm{g} \mathrm{Cu}^{2+} \mathrm{L}^{-1}\right)$ it was lower than in the control. This result is notable, as the latter treatment is representative of in-lake ionic copper concentration before D. galeata was detected in Lake Orta (cfr. Fig. 1). Furthermore, within treatment variability was large, particularly between 3.9 and $5.1 \mu \mathrm{g} \mathrm{Cu}^{2+} \mathrm{L}^{-1}$, than in the control. In the latter, mean generation time was slightly shorter than in all treatments ( 28 days with respect to 29 and 30 , at the highest and intermediate ionic copper concentrations, respectively).

Changes in net fecundity and net fertility after exposure to different levels of copper are also clear from figure 2. The increase in fecundity at 3.9-5.1 $\mu \mathrm{g} \mathrm{Cu}^{2+} \mathrm{L}^{-1}$ was accompanied by a gradual increase in the proportion of non-viable eggs. At the highest concentration abortion resulted three times higher than in the control. Because of increased abortion, a $15 \%$ increase in reproductive effort did not result in an increase in offspring production at $6.9 \mu \mathrm{g} \mathrm{Cu}^{2+} \mathrm{L}^{-1}$; in fact offspring production was significantly lower than in the control (Scheffè test; $p<0.001 ; \mathrm{N}=18$ ).

The total number of clutches produced per female over the whole duration of the experiment was slightly higher between 3.9 and $5.1 \mu \mathrm{g} \mathrm{Cu}^{2+} \mathrm{L}^{-1}$ (Tab. 3). Such an increase, however, did not result in a significant increase in the number of newborn releases per female. The latter was decreased only at the highest ionic copper tested concentration.

At concentrations slightly higher than those in the control (3.9-4.9 with respect to $3.2 \mu \mathrm{g} \mathrm{Cu}^{2+} \mathrm{L}^{-1}$ ), the intrinsic rate of natural increase was not significantly affected. At the two higher concentrations (5.1 and 6.9 $\mu \mathrm{g} \mathrm{Cu}^{2+} \mathrm{L}^{-1}$, respectively) however, values were significantly lower (Scheffè test: $p<0.001 ; \mathrm{N}=44$ ) than those observed in the other treatments and in the control (Fig. $3)$. The decrease was also related to the age at which the first clutch of newborn was released (Fig. 4): an earlier 


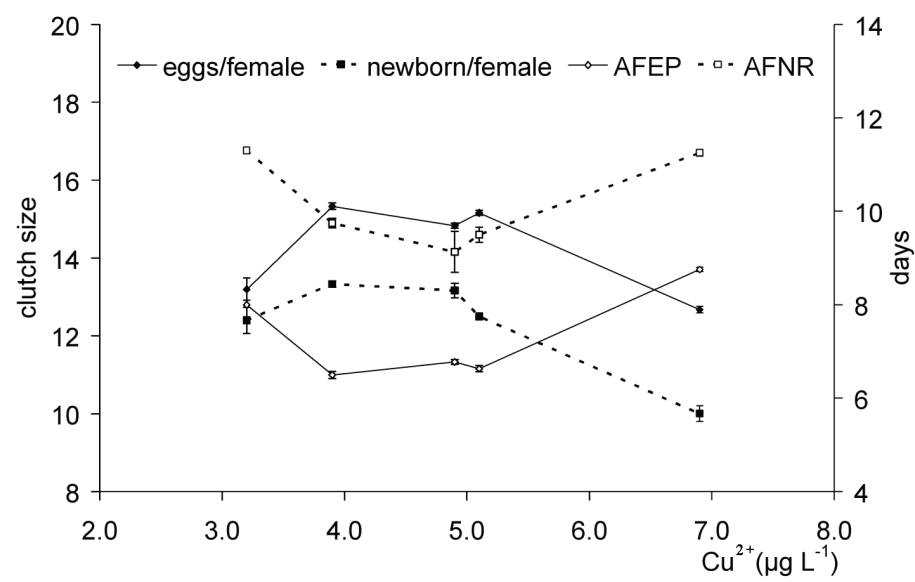

Fig. 4. Age at first egg production and at newborn release (AFEP and AFNR, respectively, days, shown on the secondary y-axix) along with the total number of egg and newborn clutches/female (shown on the primary y-axis) over the 45 days experiment. For better explanation of symbols see text.

first offspring release was found at concentrations between 3.9 and $5.1 \mu \mathrm{g} \mathrm{Cu} \mathrm{Cu}^{2+} \mathrm{L}^{-1}$ (Kruskall-Wallis test; $\mathrm{H} 4 ; \mathrm{N}=44 ; p<0.001)$; no difference was observed, however, between $6.9 \mu \mathrm{g} \mathrm{Cu}^{2+} \mathrm{L}^{-1}$ and the control.

First offspring production (total body mass expressed in $\mu \mathrm{g}$ d.w.), which is often used as a measure of fitness, was significantly lower in all treatments than in the control $(p<0.001 ; \mathrm{N}=115)$. The lower weight was the result of a lower number of newborn per clutch (on average between 2.8 and 1 in the treatments, with respect to 5 of the control) and a lower mean individual mass (on average, $3.5 \mu \mathrm{g}$ d.w. ind ${ }^{-1}$ in the treatments, with respect to $5 \mu \mathrm{g}$ d.w. ind $^{-1}$ in the control).

\section{DISCUSSION}

The range of ionic copper concentrations we used for $48 \mathrm{hrs}$ acute toxicity tests is representative of Lake Orta's pollution and of the early phase of Daphnia appearance (Fig. 1). The results of these tests indicate an exceptional high tolerance to ionic copper, three times higher than that reported for field populations of the same species (Bossuyt \& Janssen 2005). Natural populations from polluted areas may develop increased resistance to metals as a result of selective pressure (Bachiorri et al. 1991b; Klerks \& Levinton 1993). Such tolerance may have a genetic basis (adaptation), as suggested by monoclonal structure of Lake Orta's $D$. galeata population. A similar increase in tolerance to copper, zinc and cadmium has been reported for a $D$. magna laboratory clone (Muyssen et al. 2002) after an acclimation period to these metals.

The results of our experiments were based on individuals parthenogenetically produced by a $D$. galeata female from Lake Orta dominant clone in spring 2008. Allozyme analyses for the loci GPI and PGM, however, suggested an extremely homogenous composition of Lake Orta's D. galeata population in 2006 (Piscia et al. 2006), confirming results previously obtained on colonizing $D$. obtusa during the early recovery phase
(Bachiorri et al. 1991a). We interpreted our results as an evidence of a founder effect combined with a strong clone selection in a highly disturbed environment.

Because of the prevalence of a single clone, the results we obtained may be regarded as representative of the actual lake population, therefore allowing for an understanding of the role of environmental variables for the succession of Daphnia species during the lake recovery.

Our results indicate that D. galeata from Lake Orta is highly sensitive to low $\mathrm{pH}$, unlike species of the pulex group, including D. obtusa, that can grow and reproduce at low pH (Freyer 1985; Hamza et al. 1998). The low tolerance of $D$. galeata to acid conditions has been already reported in Ontario lakes (Keller et al. 1990). Our results also agree with field data from Lake Orta, where the species was able to establish only after the recovery of $\mathrm{pH}$ (Bonacina 2001). This result suggests, in turn, that the succession of the two Daphnia species was primarily regulated by $\mathrm{pH}$ conditions, although the availability of ionic copper in the lake is strongly affected by $\mathrm{pH}$ (Bonacina \& Pasteris 2001).

As reported in previous studies (Hamza et al. 1998; Bonacina \& Pasteris 2001), the gradual disappearance of D. obtusa from Lake Orta might be the result of the onset of neutral conditions not ideal for this species. However, the success of $D$. galeata was also likely favoured by $D$. galeata's lower vulnerability to fish predation, which is typical for species of the $D$. longispina complex, compared to those of the D. pulex group, to which D. obtusa belongs (Hrbáček 1987; Havens et al. 1993).

Demographic and reproductive parameters were affected by a $48 \mathrm{hrs}$ pre-exposure of newborn to sublethal concentrations of ionic copper. Concentrations only slightly higher than those presently measured in Lake Orta resulted in increased net reproduction rates, calculated from cumulative egg production, as well as newborn production, and production per female (Fig. 2). 
The proportion of non-viable eggs, however, increased in parallel, from values of $c a 16 \%$, comparable to those calculated from field data on embryo morphology, to $c a$ $30 \%$ at higher pre-exposure copper concentrations. As a consequence, net reproduction was lowered at the highest ionic copper concentration (Fig. 3), which is around two times more than the current concentration of the lake (Calderoni, pers. comm.). An earlier start of egg production and newborn release, recorded at ionic copper concentrations between 3.9-5.1 $\mathrm{g} \mathrm{L}^{-1}$ resulted in a greater number of clutches, both based on eggs and newborn. At the pre-exposure highest ionic copper concentration mothers of the same age as those in the control produced a lower number of newborn clutches.

The different pattern observed for eggs and newborn clutches and the lower numbers of clutches, were the result of egg abortion. The enhancement observed at slightly higher concentrations, however, may be interpreted as a stress response, as an increased production was also accompanied by an increased proportion of non-viable eggs (cfr. Fig. 3). Supporting this interpretation, $1^{\text {st }}$ offspring production was significantly lowered in all treatments compared to the control, as a consequence of a lower number of newborn of a smaller body size.

Our results agree fairly well with those observed after chronic exposure to ionic copper. Reproductive output can be affected directly by a toxicant (causing a change in brood size or in frequency of reproduction) or indirectly, by shortening the life span of the female or affecting age at the first reproduction. According to Winner \& Farrell (1976), chronic exposure of $D$. magna, D. galeata and D. pulex to copper did not delay age at first reproduction nor did it change the frequency of egg production. Copper did, however, affect reproductive output directly, by causing a decrease in clutch size (Winner \& Farrell 1976).

In our experiments we tested the consequences of 48 hrs exposure of $<24 \mathrm{hrs}$ old individuals to ionic copper. This differs from traditional experiments in which exposure to toxicants is applied for longer time periods. Nevertheless, our results were fully comparable to those reported in literature, therefore suggesting that the effects are mainly consequent to an early exposure of individuals to toxicants. We ran our life tables experiments for 45 days (i.e. not until all individuals were dead) under the assumption that the effects would be detectable in the time frame chosen, as it corresponds to the mean expectation of life of $D$. galeata under standard laboratory conditions (Manca \& de Bernardi 1981). Although it has been suggested that reliable estimates of demographic and reproductive parameters can be obtained from data on the first offspring release (Lampert 2000), data in literature also suggest that a delayed response can be observed under toxicants and/or unfavourable laboratory conditions (such as: poor quality food, fluctuating temperature) (de Bernardi et al. 1979; Manca et al. 1986).

\section{CONCLUSIONS}

The higher tolerance of D. galeata to ionic copper observed in the present study is likely due to the strong selective pressure in a polluted area in which only specific clones are able to grow. Such tolerance is linked to the extremely low clone diversity reported for Lake Orta's D. galeata population (Piscia et al. 2006), and probably it is the result of a genetic adaptation more than acclimation.

An increase in lake acidity causes widespread changes in zooplankton community structure (Locke 1991). Our $\mathrm{pH}$ experiments revealed that $D$. galeata is highly vulnerable to acid conditions, confirming its ability to establish in the lake only after the restoration of near-neutral conditions. On the other hand, the high tolerance of D. obtusa to acid $\mathrm{pH}$ levels allowed its earlier establishment, when the lake water was still acid (Bachiorri et al. 1991a). The succession from D. obtusa to D. galeata was therefore constrained by changes in lake water $\mathrm{pH}$, although the appearance of zooplanktivorous fish also favoured the advantage of the latter (Bonacina \& Pasteris 2001).

An apparent stimulation of reproduction effort due to increasing eggs production after a pre-exposure of newborn to ionic copper concentrations slightly higher than those presently measured in the lake, was negated by an increased percentage of aborted eggs, indicating that organisms were under a stress condition. This was also confirmed by a gradual decrease in fitness observed along with increasing ionic copper concentrations. Exposure to a level of copper comparable to that measured just before the onset of $D$. galeata in the lake resulted in a reduction of the intrinsic rate of population increase and newborn production. Such a reduction, however, was not sufficiently high to justify an effective chronic damage to the population (Roex et al. 2000).

\section{ACKNOWLEDGEMENTS}

We would like to thank G. Tartari and Dr. O. Tornimbeni of the hydrochemistry laboratory for ionic copper analysis and useful suggestions during the experimental work. Research supported by CNR RSTL094.009 to M. Manca. We are also very grateful to four reviewers for their critical comments and helpful suggestions.

\section{REFERENCES}

Bachiorri, A., V. Rossi, C. Bonacina \& P. Menozzi. 1991a. Enzymatic variability of a colonizing population of Daphnia obtusa Kurz (Crustacea: Cladocera). Verh. int. Ver. Limnol., 24: 2813-2815.

Bachiorri, A., V. Rossi \& P. Menozzi. 1991b. Differences in demographic parameters among electrophoretic clones of Daphnia obtusa Kurz (Crustacea: Cladocera). Hydrobiologia, 225: 263-268.

Barata, C., D.J. Baird \& S.J. Markich. 1998. Influence of genetic and environmental factors on the tolerance of Daphnia magna Straus to essential and non-essential metals. Aquat. Toxicol., 42: 115-137. 
Bonacina, C. 2001. Lake Orta: the undermining of an ecosystem. J. Limnol., 60: 53-59.

Bonacina, C. \& A. Pasteris. 2001. Zooplankton of Lake Orta after liming: an eleven year study. J. Limnol., 60: 101-109.

Bossuyt, B.T.A. \& C.R. Janssen. 2003. Acclimation of Daphnia magna to environmentally realistic copper concentration. Comp. Biochem. Physiol., 136: 254-264.

Bossuyt, B.T.T. \& C.R. Janssen. 2005. Copper toxicity to different field-collected cladoceran species: intra- and interspecies sensitivity. Environ. Pollution, 136: 145-154.

Calderoni, A., R. Mosello, A. Quirci \& R. de Bernardi. 1990. Recovery of Lake Orta by liming. Proc. VII Int. Lime Congr. Rome, 13-14 September 1990: 157-171.

Cattaneo, A., A. Asioli, P. Comoli \& M. Manca. 1998. Organisms' response in a chronically polluted lake supports hypothesized link between stress and size. Limnol. Oceanogr., 43: 1938-1943.

de Bernardi, R., G. Giussani \& E. Lasso Pedretti. 1979. Food suitability and availability, demographic parameters and population growth in Daphnia obtusa Kurz under laboratory conditions. In: R. de Bernardi (Ed.), Biological and mathematical aspects in population dynamics. Mem. Ist. ital. Idrobiol., Suppl. 37: 233-242.

de Bernardi R. \& M. Manca. 1981. Energy reserves and timelags in the population dynamics of Daphnia, In: Moroni, A., O. Ravera \& A. Anelli, Atti del $1^{\circ}$ Congresso Naz. Della S.IT.E. Salsomaggiore Terme (Parma): 21-24 Ottobre 1980: 189-194.

de Bernardi R. \& M. Manca. 1982. The consequences of life history strategies on competition between two cladocerans. Mem. Ist. ital. Idrobiol., 40: 145-161.

Freyer, G. 1985. The ecology and distribution of the genus Daphnia (crustacea: cladocera) in restricted areas: the pattern in yorkshire. J. Nat. Hist., 19: 97-128.

Hamza, W., C. Bonacina \& C. Canale. 1998. Effect of water acidity and recovery on the viability of both Daphnia longispina (O.F. Müller) and Daphnia obtusa (Kurz) in Lake Orta (N. Italy). Verh. int. Ver. Limnol., 26: 19361940.

Havens, K.E., N.D. Yan \& W. Keller. 1993. Lake acidification: effect on crustacean zooplankton populations. Environ. Sci. Technol., 27: 1621-1624.

Hrbàcek, J. 1987. Systematics and biogeography of Daphnia species in the Northern temperate regions. In: R.H. Peters \& R. de Bernardi (Eds). Daphnia. Mem. Ist. ital. Idrobiol., 45: 37-76.

Keller, W., N.D. Yan, K.E. Holtze \& J.R. Pitblado. 1990. Interred effect of lake acidification on Daphnia galeata mendotae. Environ. Sci. Technol., 24: 1259-1261.

Klerks, P.L. \& J.S. Levinton. 1993. Evolution of resistance and changes in community composition in metal-polluted envitonments: a case study on Foundry cove. In: R. Dallinger \& P.S. Rainbow (Eds), Ecotoxicology of metal in invertebrates. Lewis Publisher, Boca Raton: 223-241.

Lampert, W. 2000. Survival in a varying environmental: phenotypic and genotypic responses in Daphnia populations. Limnetica, 20: 3-14.

Received: January 2010

Accepted: March 2010
LeBlanc, G.A. 1982. Laboratory investigation into the development of resistance of Daphnia magna (Straus) to environmental pollutants. Environ. Pollution, 27: 309-322.

Locke, A. 1991. Zooplankton responses to acidification: a review of laboratory bioassays. Water, Air, \& Soil Pollution, 60: $135-148$

Long, K.E., E.J. Van Genderen \& S.J. Klaine. 2004. The effect of low hardness and $\mathrm{pH}$ on copper toxicity to Daphnia magna. Environ. Toxicol. Chem., 23: 72-75.

Manca, M. \& P. Comoli. 1995. Temporal variations of fossils Cladocera in the sediments of Lake Orta (N. Italy) over the last 400 years. J. Paleolimnol., 14: 113-122.

Manca, M. \& P. Comoli. 2000. Biomass estimates of freshwater zooplankton from length-carbon regression equations. J. Limnol., 59(1): 15-18.

Manca, M., R. de Bernardi \& A. Savia. 1986. Effect of fluctuating temperature and light conditions on populations dynamics and life strategiesof migrating and non migrating Daphnia species. Mem. Ist. ital. Idrobiol., 44: 177-202.

Matthes, M. 2004. Low genotypic diversity in a Daphnia pulex population in a biomanipulated lake: the lack of vertical and seasonal variability. Hydrobiologia, 526: 33-42.

Meyer, J.S., C.G. Ingersoll, L.L. McDonald \& M.S. Boyce. 1986. Estimating uncertainly in population growth rates: jackknife $v s$ bootstrap techniques. Ecology, 67: 1156-1166.

Monti, R. 1930. La graduale estinzione della vita nel limnobio del Lago d'Orta. Rend. Ist. Lomb. Sc. Lett., 63: 3-22.

Muyssen, B.T.A., C.R. Janssen \& B.T.A. Bossuyt. 2002. Tolerance and acclimation to zinc of field-collected Daphnia magna populations. Aquat. Toxicol., 56: 69-79.

Organisation for Economic Co-Operation and Development (OECD). 1996. Daphnia sp. immobilisation test and reproduction test 202. In: OECD guidelines for testing chemicals. OECD, Paris: 21 pp.

Pavesi, P. 1879. Ulteriori studi sulla fauna pelagica dei laghi italiani. Rend. R. Ist. Lomb. Sc. Lett., 12: 688-707.

Piscia, R., J. Sěda, C. Bonacina \& M. Manca. 2006. On the presence of Daphnia galeata in Lake Orta (N. Italy). J. Limnol., 65(2): 114-120.

Roex, E.W.M., C.A.M. Van Gestel, A.P. Van Wezel \& N.M. Van Straalen. 2000. Ratios between acute aquatic toxicity and effects on population grow rates inrelation to toxicant mode of action. Environ. Toxicol. Chem., 3: 685-693.

Ruggiu, D., A. Luglié, A. Cattaneo \& P. Panzani. 1998. Paleoecological evidence for diatom response to metal pollution in Lake Orta (N. Italy). J. Paleolimnol., 20: 333-345.

Seber, G.A.F. 1973. The estimation of animal abundance and related parameters. Griffin, London: $506 \mathrm{pp}$.

Winner, R. W. \& M. P. Farrell. 1976. Acute and chronic toxicity of copper to four species of Daphnia. J. Fish. Res. Bd. Can., 33: 1685-1691.

Wolinska, J., B. Keller, M. Manca \& P. Spaak. 2006. Parasite survey of a Daphnia hybrid complex: host-specifity and environmental determine infection. J. Animal. Ecol., 76: 191-200. 